\title{
Linda Jonsson
}

Mälardalens högskola

Niclas Månsson

Södertörns högskola

DOI: http://dx.doi.org/10.5617/adno.8767

\section{Med en tydlig utgångspunkt i kristendomens synsätt och traditioner - om religionskunskapsämnets alkemi}

\begin{abstract}
Sammanfattning
I den här artikeln utgår vi från religionsämnets reformering 2011 med syfte att ringa in vad ett mer faktabaserat och rationellt förhållningssätt till andra religioner samt vad företrädet för kristendom kan betyda för ämnets fostrande roll och uppgift på gymnasieskolan. För att förstå vad ämnets innehåll och syfte innebär som en del i formandet av den önskade samhällsmedlemmen, utgår vi från Popkewitz förståelse av alkemi och analyserar ämnet i ett historiskt och teoretiskt perspektiv. Genom en konceptualisering av ämnet över tid identifieras fyra vågor som format ämnet: en konfessionell våg, en objektiv våg, en osäker våg och en våg som benämns objektiv 2.0. Den första vågen karaktäriseras av ett väl avgränsat kristendomsämne med tydligt syfte och innehåll. Den önskade eleven är ett lydande och underdånigt barn med rötter i den kristna läran. Den andra vågen förstås bäst utifrån sin objektiva orientering. Den önskade eleven är vidsynt och tolerant med en god förståelse för kristendom och andra religioner samt existentiell pluralism. Den tredje vågen visar ett religionskunskapsämne med stor spännvidd och gränslöst innehåll. Den önskade eleven är vidsynt med god förståelse för religiös och existentiell mångfald förankrat i en kristen tradition och västerländsk humanism. Den kristna underströmmen når i och med den fjärde vågens inramning återigen ytan. Inramningen och avgränsningen sker genom ett fokus på faktakunskaper och ett vetenskapligt-rationellt förhållningssätt samt förståelse för religion som ett socialt snarare än ett existentialistiskt fenomen. Vi avslutar artikeln med att diskutera några didaktiska implikationer relaterade till reformen 2011.
\end{abstract}

Nyckelord: religionskunskap, alkemi, socialisation, läroplan, didaktik

\section{With a Departure in Christianity - the Alchemy of Religion Education}

\begin{abstract}
This article has a point of departure in the reform of Swedish upper secondary education in 2011. Here, the focus of the school subject of religion shifted from different religious perspectives, various existential questions, and pupil-initiated questions, to an emphasis based on a scientific-rational content, with an exceptional position for Christianity compared to other world religions. This article aims to clarify the implications of this shift for the purpose, content, and socializing dimension of the subject of religion for
\end{abstract}


Swedish upper secondary school. We depart from Popkewitz's understanding of Alchemy and analyze the purpose of religion education through a historical and theoretical approach. By conceptualizing the purpose and content of the school subject of religion over time and relating it to the 'zeitgeist', we identified four different 'waves' of religion education, ranging from its past clerical focus to the present-day's nondenominational and scientific orientation. First, the 'confessional wave' focused on the clerical Christian inheritance in order to produce subservient and Christian citizens. Second, the 'objective wave' aimed to educate objective and broad-minded citizens, responsive to religious plurality. Thereafter, in the 'uncertain wave', religion studies became a matter of subjective beliefs, focusing on learning from their encounters with other persons in order to become broad-minded citizens, with an understanding of religious and existential plurality. Finally, the curriculum from 2011 gave birth to an 'objective wave 2.0', with the purpose to educate rational citizens with a scientific view on religion as a social phenomenon. We conclude the article by discussing some didactical implications of the 2011 reform.

Keywords: religion education, alchemy, socialization, curriculum, didaktik

\section{Inledning}

Skolämnet religionskunskap är behäftat med en inneboende komplexitet då religionsläraren måste finna en balans mellan fakta och föreställningar (Kittelmann Flensner, 2015; Jonsson, 2016). Samtidigt som undervisningen ska vara saklig och allsidig ska läraren bemöta frågor om elevers egna religiositet eller livsåskådning i förhållande till andra elevers religiositet eller livsåskådningar samt etiska och existentiella frågor som har betydelse för deras förståelse av sig själva och sin omvärld. Skolan, liksom dess klassrum är en reflektion av det omgivande samhällets tillstånd. I ett samhälle som präglas av kulturell samt tros- och livsåskådningsmässig mångfald och olikhet, präglas också skolan och dess klassrum av samma mångfald. Därmed är en av skolans uppgifter att förbereda den uppväxande generationen för en allt mer pluralistisk och globaliserad värld med ett spektrum av föreställningar där inte sällan tros- eller livsåskådning utgör kärnan för en persons eller grupps uttryckta livsstil.

När den nya kursplanen för ämnet religionskunskap implementerades i den svenska gymnasieskolan 2011 (Gy 11) stod inte det spektrum av livsåskådningar som präglar det mångkulturella samhället i fokus. Ämnet gick istället från ett mer individuellt elevnära perspektiv, med fokus på existentiella och etiska spörsmål, till ett mer rationaliserande samt kunskapsinhämtande och faktabaserat förhållningssätt till religioner och andra livsåskådningar. Även om det finns flera källor som fokuserat den uttalade skillnaden mellan 1994 och 2011 års läroplan där omdaning till ett faktabaserat och kunskapsinhämtande ämne i relation till behovet av existentiella och elevnära frågor belyses och diskuteras - på forskningsnivå (se exempelvis Kittelmann Flensner, 2015; Jonsson, 2016), på religionslärarnas föreningsnivå (se Religion \& Livsfrågor, 2011) och på 
myndighetsnivå (se Skolinspektionen, 2012) - har frågan om reformens didaktiska konsekvenser inte belysts på djupet, vare sig i ett nutida eller i ett historiskt perspektiv. Då ämnet historiskt sett haft en dominerande roll när det kommer till skolans fostrande uppdrag, oavsett om undervisningen varit konfessionell eller inte, är artikelns problemställning vad 2011 års reform innebär för religionsämnets fostrande ambitioner och hur reformens framväxt kan förstås i ett historiskt perspektiv.

För att kunna uttala oss om ämnets ambitioner idag, anlägger vi en historisk relief i vår genomgång och analys av det insamlade material som ligger till grund för studien. Ett första syfte med studien är att förstå hur kristendomsämnets, sedermera religionskunskapsämnets, fostrande ambitioner kommit till uttryck och hur de ändrats över tid i relation till tidsandan. Ett andra syfte är att diskutera och problematisera de didaktiska implikationer som följer av revideringen av religionsämnet i Gy 11 ur såväl ett allmändidaktiskt som ett ämnesdidaktiskt perspektiv.

\section{Allmän didaktik och ämnesdidaktik}

Didaktik handlar om formaliserade undervisnings- och lärandeprocesser och delas traditionellt sett upp i tre delar: innehåll (som handlar om vad som ska läras ut), metod (som handlar om hur detta ska läras ut) och legitimitet (som handlar om varför detta ska läras ut). Dessa delar utspelar sig dels på en utbildningspolitisk nivå, vilken kommer till uttryck i en given läroplan med tillhörande kursplaner för respektive ämne, dels på en konkret nivå, realiserad i olika undervisningssituationer där innehållet ska levandegöras och komma eleverna till gagn (von Oettingen, 2018). Dessa nivåer förenas så till vida att det som uttrycks i en läroplan respektive kursplan ska realiseras i faktiska undervisningssituationer.

Didaktiken är vanligtvis uppdelad i en allmän del och en ämnesdidaktisk del. För den allmänna didaktiken är det brukligt att tala om undervisning i mer generella termer, vilka inte nödvändigtvis är knutna till ett ämne. Det handlar då om undervisningens organisation, klassrummets sociala relationer, de ramfaktorer som reglerar den formella undervisningen och samhällets ambitioner, eller andra faktorer som ställer krav på undervisningens eller lärandets förutsättningar (von Oettingen, 2018; Nordmark, Jonsson \& Månsson, 2018).

Ämnesdidaktiken handlar om kunskaper om ämnets innehåll och selektiva traditioner samt om undervisning i det aktuella ämnet (Englund, 2007; Bronäs \& Runebou, 2010). I det här fallet handlar det om religionskunskapsämnet i gymnasieskolan. Ämnesdidaktiken kan inte enbart adderas till ämnet som det ska undervisas i utan att beakta dess allmändidaktiska dimension. Därför beskrivs ämnesdidaktiken ibland som en bro mellan ämnesteori och allmän didaktik och utgör den överlappning mellan ämnesaspekter och undervisningsproblematik som tillsammans utgör något nytt (Blankertz, 1987; Bronäs \& Runebou, 2010). 
Att religionskunskapsämnet har ett demokratiskt och medborgarbildande uppdrag understryker Maria Olson (2017) och låter jämföra religionskunskapsämnet med skolans övriga samhällsorienterande ämnen. Detta visar hur identitet och berättigande särskilt lyfts fram i religionskunskapen. I flera religionsdidaktiska studier synliggörs hur begrepp och faktakunskaper får stå tillbaka till förmån för en religionskunskapsundervisning med fokus på levd religion i termer av känslor och upplevelser (Holmqvist Lidh, 2016; Kittelmann Flensner, 2015, 2018). Thérese H. Britton (2019) låter fokus på levd religion följa med då hon undersöker hur en studiebesöksorienterad undervisning kan utveckla elevers förståelser för olika religioner. Med ett perspektiv med kopplingar till Michael Grimmitts (1987) terminologi att lära av, om eller $i$ religion tar Nigel Fancourt (2008) ett grepp om den engelska religionsundervisningen och åskådliggör elevers kunskapsutveckling i förhållande till lärande om och $a v$ religioner. I en norsk studie (von der Lippe, 2010) visas hur tonåringar i ett mångkulturellt och sekulariserat sammanhang tänker och talar om religioner. Studier har också fokuserat och granskat miljöns förutsättningar där religionskunskapsundervisningen äger rum med begreppet "safe space” som utgångspunkt (Osbeck, Sporre \& Skeie, 2017; Kittelmann Flensner \& von der Lippe, 2019). Ett exempel på hur relationen mellan interkulturell pedagogik och religionsdidaktik kommer till uttryck ges i ett temanummer i Intercultural Education (redigerat av Jackson, 2019). Här ges i ett flertal texter en internationell utblick som uppmärksammar förhållandet mellan religion och samhälle i en interkulturell nutida kontext.

Eftersom den allmänna didaktiken snarare handlar om bildning än undervisning är den inte ett föremål för bedömning och betygsättning utan ingår i skolans värdegrund. Detta betyder inte att den allmänna didaktiken är frånskild undervisningen eftersom det innehåll som utgör skolans värdegrund mycket väl kan vara vägledande för hur läraren väljer ut innehållet i ämnet och utformar sin undervisning (Nordmark, Jonsson \& Månsson, 2018). Därmed ser vi denna text som en studie i allmän didaktik med ett religionsdidaktiskt ärende, nämligen ämnets roll för skolans samhällsfostrande uppdrag, oavsett om det handlar om att lära $a v$, om eller $i$ religion.

\section{Undervisningens ambitioner}

Samhällets ambitioner med den offentliga undervisningen framträder i 2011 års läroplan för gymnasieskolan (Gy 11) där det framgår att "[u]tbildningen ska förmedla och förankra respekt för de mänskliga rättigheterna och de grundläggande demokratiska värderingar som det svenska samhället vilar på” (s. 5). Lite längre ned tydliggörs utbildningens värdeförmedlande, eller fostrande, uppdrag: "I överensstämmelse med den etik som förvaltats av kristen tradition och västerländsk humanism sker detta genom individens fostran till rättskänsla, generositet, tolerans och ansvarstagande” (s. 5). Det framgår också att 
utbildningen ska anpassas till varje individs förutsättningar och behov, vara likvärdig, icke-konfessionell och "främja elevernas utveckling till ansvarskännande människor, som aktivt deltar i och utvecklar yrkes- och samhällslivet” (s. 6).

Religionskunskapsämnets ambitioner - med avseende på såväl syfte som innehåll - så som de uttrycks i ämnesplanen (Gy 11, s. 137-142) handlar om att eleverna ska bredda, fördjupa och utveckla "kunskaper om religioner, livsåskådningar och etiska förhållningssätt och olika tolkningar när det gäller dessa” (s. 137) som leder till ett utvecklande av "kunskaper om hur människors moraliska förhållningssätt kan motiveras utifrån religioner och livsåskådningar” (s. 137). Det framgår av ämnesplanens formuleringar att genom att "reflektera över och analysera människors värderingar och trosföreställningar [...]" ska eleverna "utveckla respekt och förståelse för olika sätt att leva" (s. 137).

Därmed ska ämnet bidra till kunskap, analytisk förmåga, vidsynthet, öppenhet och förståelse för andra religioner och livsåskådningar än sin egen, dock med en tydlig utgångspunkt i kristendomens synsätt och traditioner. Till skillnad från föregående kursplan (Lpf 94) handlar det för eleven om att få kunskap om olika religioner och livsåskådningar, inte lära sig $a v$ dessa, och att analytisk kunskap ges prioritet framför personlig utveckling (Kittelmann Flensner, 2015, s. 42-44). Enligt ämnesplanens skrivelse handlar det om insikten att "[k]unskaper om samt förståelse för kristendomen och dess traditioner har särskild betydelse då denna tradition förvaltat den värdegrund som ligger till grund för det svenska samhället” Gy 11, s. 137). I detta sammanhang bakas ämnesplanen samman med den allmänna skrivningen om skolans värdegrund som tecknats ned i läroplanens inledande del, nämligen att det är kristendomen som "förvaltat den värdegrund som ligger till grund för det svenska samhället” (s. 5). Det är i detta avseende som religionskunskapsämnets fostrande ambitioner inte enbart blir en ämnesdidaktisk uppgift utan också är en allmändidaktisk uppgift eftersom de allmänna utbildningsmålen, enligt Herwig Blankertz (1987, s. 135), ger uttryck för "summan av samtliga skolämnens utbildningsmål”.

Förutom ämnets ambitioner anges dess centrala innehåll och kunskapskrav (i relation till det graderade betygssystemet $\mathrm{E}-\mathrm{A}$ ) och antalet undervisningstimmar för Religion 1 är 50 poäng (Gy 11). Oavsett tid, bedömning och kunskapskrav är det ämnets syfte och innehåll som blir relevant i detta sammanhang då dessa så tydligt kopplas till samhällets ambitioner med undervisningen som sådan, och det diskuterar vi fortsättningsvis i termer av alkemi.

\section{Religionskunskapsämnets alkemi}

Basil Bernstein (1971) har visat hur olika undervisningsämnen skiljer sig åt i hur de framställs i läroplaner samt kursplaner och diskuterar detta i termer av inramning och avgränsning. Här skiljer Bernstein mellan två olika läroplanskoder: 
kollektionskod och integrationskod. Den första följer strikta mönster med utgångspunkt i detaljerade kursplaner, läraren förmedlar kunskap och eleven är mottagaren. Integrationskoden däremot innebär en försvagning av detaljerad styrning och elevinflytande ses som en förutsättning för såväl undervisningens gestaltning som innehåll. Ju mer detaljerade och utförliga anvisningarna i en läroplan är desto starkare gränser karaktäriserar varje enskilt undervisningsämne (Bernstein, 1971). Det är tydligt att religionskunskapsämnets utveckling från Lpf 94 till Gy 11 gått från en integrationskod eftersom Gy 11 tar mer fasta på att eleven ska erhålla kunskaper om andra religioner, snarare än vad eleven kan lära sig $a v$ andra religioner, att analytisk kunskap sätts framför personlig utveckling och att betygskriterierna är mer kunskapsrelaterade än värderelaterade (Kittelmann Flensner, 2015, s. 42-44).

Det gymnasiegemensamma ämnet religionskunskap har sin förankring i religionsvetenskapen, som bedriver vetenskapliga studier av religioner och livsåskådningar. Även om skolämnet religionskunskap har sin ämnesteoretiska och vetenskapliga förankring i sin moderdisciplin sker något med ämnet på dess väg till att bli ett skolämne. Då det handlar om en form av en organiserad transformativ process, snarare än en översättning av det vetenskapliga ämnet, måste detta relateras till och anpassas efter skolans ramar, schema, antal timmar, undervisningens innehåll, elevernas ålder, undervisningens organisering, teorier om undervisning och lärande (Goodson, 2005; Popkewitz, 2010). Eftersom ämnets innehåll och utformning ändras över tid måste också de sociala och kulturella förhållanden som ligger till grund för formerandet av ett skolämne tas i beaktande (Goodson, 2005).

Skolämnen kommer och går och förändras till innehåll och utformning, exempelvis blev ämnet kristendomskunskap religionskunskap för grundskolan 1969 (Lgr 69) samt för Fackskolan 1965 (Lgy 65) och den allmänna gymnasieskolan 1970 (Lgy 70) och bytte därefter skepnad från en konfessionell undervisningsform till en icke-konfessionell sådan (Jonsson, 2016). Ett ämnes förändring ligger i den dominerande uppfattningen om vad den uppväxande generationen behöver för att tillsammans med andra leva och verka i ett givet, men över tid föränderligt samhälle (Goodson, 2005). I ett mångreligiöst och mångkulturellt samhälle, som den svenska gymnasieskolan är verksam i och utgör en del av, finns det med andra ord en tydlig vits med att besitta "kunskaper om hur människors moraliska förhållningssätt kan motiveras utifrån religioner och livsåskådningar" och kunna "reflektera över och analysera människors värderingar och trosföreställningar [...] utveckla respekt och förståelse för olika sätt att leva” (Gy 11, s. 137).

Den amerikanske pedagogen Tom Popkewitz (2002, 2004, 2009, 2010) använder analogin alkemi för att beskriva transformationen från vetenskapligt kunskapsområde till ett skolämne: "Liksom de medeltida alkemisterna sysslade med att omvandla ämnen från ett område till ett annat, så transformerar pedagogiken 
på ett magiskt sätt natur-, samhälls- och humanvetenskaperna till 'ting' som lärs ut i skolorna” (Popkewitz, 2009, s. 156).

Alkemin - som analytiskt verktyg för att förstå transformationen från ett akademiskt kunskapsområde till ett skolämne och dess undervisningsformer visar sig först då det akademiska kunskapsområdet flyttar in i skolans värld. Popkewitz menar att "läroplanen alltid är en alkemi-översättningarna är skapelser och inte kopior av originalen” (Popkewitz, 2010, s. 417, vår översättning). Det ämnesinnehåll som beskrivs i läroplanen för vart och ett av ämnena och organiseringen av dessa har, säger Popkewitz (2009), knappast något att göra med normerna kring status, sanningsanspråk och erkännande inom de akademiska fält som översatts till skolämnen. Det handlar om ett ämnes förvandling från disciplinärt ämne till ett skolämne för att passa den struktur som skolan befinner sig i. Alkemin behandlar skolämnena som samstämmiga och enhetliga för att dölja undervisningens normaliserande och uppdelande praktiker, som endera stödjer, endera utesluter elever med exempelvis speciella behov (Popkewitz, 2004, 2010). De styrande principerna i denna förädlande och politiskt styrda process utgörs inte av ämnets innehåll utan pedagogikens psykologiska principer, och Popkewitz menar att det handlar om att styra barnets beteende, personlighet, relationer och känslor för att inordna barnet i en viss regelbundenhet och samhällelig ordning (Popkewitz, 2004).

Enligt Popkewitz utgör den pedagogiska psykologin (likt det vi benämner som allmän didaktik) den allmänna fostrande praktik som formar elevens sätt att tänka och vara: "Pedagogikens psykologi är historiskt sett designat att styra vem barnet är och ska bli, oavsett om det handlar om att bli en problemlösare, en god samhällsmedlem, om livslångt lärande och så vidare” (Popkewitz, 2010, s. 413, vår översättning). Det som skrivs in i barnet genom pedagogikens psykologiska principer är sociala uppfattningar om vem det goda barnet är och som använder sitt förnuft på det sätt som hon eller han har lärt sig. Alkemin är också åldersrelaterad eftersom översättningarna från det akademiska kunskapsområdet till ett skolämne inte enbart varierar över tid utan ser olika ut beroende på vilket skolår, eller stadie, ämnet är tänkt för. För vår del handlar det om det gymnasiegemensamma ämnet religionskunskap och därför fokuseras på vem den önskade eleven är och förväntas att bli.

\section{Metod och material}

Det material som ligger till grund för denna studie utgörs i första hand av undervisningsplaner och läroplaner för folkundervisning $(1842,1882)$, folkskola (1878, 1919, 1955), grundskola $(1963,1969,1994)$, fackskola (1965) och gymnasieskola (1970, 1994, 2011). Övriga analyserade dokument utgörs av Statliga offentliga utredningar (SOU 1948:27; SOU 1961:31; SOU 1963:42; SOU 2008:27) som haft särskild betydelse för den svenska gymnasieskolans utveckling. 
I studien betraktas läroplanen med de tillhörande kursplanerna som tidsbundna normativa dokument med politiska ambitioner (Englund, 2005). Läroplanen för exempelvis gymnasieskolan (Lgy 70; Lpf 94; Gy 11) speglar statens ambitioner med skola och utbildning av den uppväxande generationen och är således ett normativt dokument som formar övergripande innehåll och inriktning över tid (Popkewitz, 2004; Englund, 2005). Även om läroplanstexternas ambitioner att förmedla gymnasieskolans innehållsliga inriktning inte alltid är samstämmiga, styrs de av samhälleliga tendenser eller behov i talet om skolans innehåll och syfte (Popkewitz, 2004). I denna studie har vi lagt särskild vikt vid att studera kristendomskunskapens, sedermera religionsämnets fostrande ambitioner i relation till dess syfte och innehåll för att tydliggöra hur ämnet varit en del av skapandet av den önskade eleven över tid.

I arbetet med att analysera studiens empiri använde vi oss av en syftesrelaterad textanalys i enlighet med Säfström och Östman (1999a, 1999b), vilket innebär att vi utgår från artikelns syfte och att vi inte har ambitionen att beskriva tillvaron som redan given och att den därför är i avsaknad av universalistiska anspråk. Analysen är på en deskriptiv nivå eftersom styrdokument inte är formulerade som subjektiva uppfattningar, och utgör därför ett bidrag till "ett fortgående samtal om de fenomen eller händelser som fokuseras” (Säfström \& Östman 1999b, s. 115) och i föreliggande studie om ett betraktelsesätt av det vi benämner som tidstypiska vågor. Analysen visar med andra ord att de tidstypiska sätt dokumenten utrycker sig på angående ämnets syfte, innehåll och ambitioner påverkar ämnets utformning och således även urval och undervisningsformer.

I resultatdelen ges ett historiskt tillbakablickande perspektiv som anknyter till det Englund (2005) benämner som den svenska utbildningens tre vågor, uttryckta i konceptioner: den patriarkaliska, den vetenskapligt-rationella och den demokratiska konceptionen. Englund påvisar härigenom hur den svenska utbildningshistorien gått från en "selektivt underdånighetsfostrande skola till en kollektivt demokratifostrande skola" (Englund, 1992, s. 88). Till skillnad från Englund (2005) som fokuserar skolans övergripande roll för fostran, oavsett ämne, under olika epoker, belyses här kristendomskunskapsämnet, sedermera religionskunskapsämnets fostrande roll i relation till skolans övergripande mål. Då konceptioner är mer paketerande i sin form där en utbildningskonception ersätter en annan, och avser skolans övergripande mål, oavsett ämne (Englund, 2005; Jonsson, 2016), görs i det följande en historisk konceptualisering av kristendomsämnet, sedermera religionskunskapsämnet i relation till de fyra vågor vi identifierat utifrån materialet och tidigare forskning: "Den konfessionella vågen", "'Den objektiva vågen”, ”Den osäkra vågen” och "Mot en objektiv våg 2.0?”. Precis som en våg inte helt försvinner utan lämnar ifrån sig efterdyningar eller blir en del av en annan våg, förändras heller inte ett ämne helt från en läroplan eller tidsepok till en annan. Vissa saker ersätts med andra, andra saker blir kvar om än $i$ ändrad form, likt en efterdyning som påverkar ämnets identitet och kontinuitet (Goodson, 2005). 
Som ett första steg i analysen närläste vi styrdokumenten för att därefter, i enlighet med Säfström och Östman (1999b), kunna identifiera tidstypiska formuleringar i relation till den aktuella samhällskontexten. Sådana tidstypiska formuleringar exemplifieras i termer av gudsfruktan och disciplinering vid den tidiga folkskolans inrättande, vilket vi fångar i ämnets konfessionella förhållningssätt, med en undervisning $i$ snarare än om den kristna läran - Den konfessionella vågen. Den andra våg vi identifierade kännetecknas av att ämnet framhålls i termer av neutralitet, allsidighet och existentialism, vilket vi definierar som en objektiv hållning till ämnet - Den objektiva vågen. I och med den rådvillhet som rådde över ämnets syfte och innehåll blev ämnet något annat, vare sig konfessionellt eller objektivt, och med tanke på den osäkerhet kring detta 'något annat' definierar vi den tredje vågen som Den osäkra vågen. I den för dagen aktuella ämnesplanen är vetenskaplighet, fakta och analytisk förmåga exempel på tidstypiska formuleringar. Eftersom dessa uttryckssätt om ett faktabärande ämne på vetenskaplig grund är snarlika med dem som kom till uttryck under den objektiva vågen har vi valt att benämna den fjärde vågen för Den objektiva vågen 2.0?. Det var just styrdokumentens och samhällsandans specifika vokabulär som ägnades särskild uppmärksamhet i den andra omgången av vår genomläsning. De tidstypiska formuleringar som identifierats i första genomläsningen blev sedan möjliga att i ett tredje steg av genomläsningen operationalisera och relatera till studiens teoretiska ramverk och den rådande samhällsandan.

Analyserna av den insamlade empirin utfördes därmed abduktivt, då tolkningen av den insamlade empirin gjordes i relation till studiens teoretiska föreställningar (Alvesson \& Sköldberg, 2017). I detta fall handlar det om Bernsteins (1971) teoretiska resonemang om läroplanskoder med begreppsparen kollektionskod och integrationskod samt om Popkewitz (2009, 2010) teori om skolämnets alkemi och det önskade barnet. För att ytterliga bringa förståelse för den insamlade empirin används tidigare forskning för att ringa in den tidsanda som de olika epokerna kännetecknas av, och som påverkar ämnets utformning och fostrande ambitioner (Algotsson, 1975; Lundgren, 1979; Hartman, 2009, 2010; Kittelmann Flensner, 2015; Jonsson, 2016). Att ett skolämne inbegriper en viss fostran eller inordning blir dess ambitioner inte speciellt begripliga om skolämnet inte kopplas till den rådande tidsandan (Englund, 1992).

Från genomgångarna av ovanstående styrdokument och utredningar tillsammans med grundläggande teoretiska begrepp, tidigare forskning om ämnet och tidsandan, blir det med andra ord möjligt att dels ringa in de särskilda karaktäristika som kännetecknar både ämnets fostrande ambitioner och det önskade barnet, dels att teoretiskt förstå de didaktiska implikationerna som medföljer skol- och ämnesreformer. 


\section{Resultat}

Det samtida religionskunskapsämnet, dess syfte och innehåll, vilar på traditioner bakåt i tiden som har betydelse för dagens läraruppdrag och undervisning. Under ett tidsspann omfattande knappt tvåhundra år av Sveriges historia har ämnet genomgått stora förändringar. För att belysa dessa förändringar och hur de påverkar bilden av den önskade eleven, lyfter vi i denna del fram exempel på vad ämnet kristendomskunskap sedermera religionskunskap syftat till över tid.

\section{Kristendomsämnet och den konfessionella vågen}

Den första vågen karaktäriseras av konfessionell kristendomskunskap. Inom en period omfattande drygt etthundra år, från 1842 års inrättade folkskola fram till 1950-talets begynnande reformer av det svenska utbildningsväsendet, kom skolans kristendomsundervisning att stå i centrum för omfattande förändringar. Många är de läroplaner som reglerat kristendoms- och religionskunskapsundervisningen i svenskt skolväsen. För folkskolans del gällde normalplanerna, vilka var centralt utarbetade riktlinjer för lokala läroplaner (Algotsson, 1975). Länge sågs kristendomskunskapen som det tyngsta och mest statusfyllda ämnet i skolan med ett innehåll baserat på moraliska värden uttryckta i konfessionell kunskap om kristendom och detta med syfte att genomsyra och prägla hela skolverksamheten. I Folkskolestadgan av år 1842 anges ingen konkret läroplan och inte några målformuleringar för enskilda ämnen. Dock understryker den att folkskolan står under kyrkans ledning när det gäller undervisningens ideologiska profilering i termer av kristendomskunskap och katekesläsning. För den blivande lärarens del preciseras i Folkskolestadgans sjätte paragraf att "gudsfruktan och sedlig vandel” är fundamentet som läraruppdraget med nödvändighet ska vila på (Algotsson, 1975; Lundgren, 1979; Jonsson, 2016). Det övergripande målet med skolans undervisning var således att inpränta gudsfruktan hos eleverna, skapa gemensamma normer och en gemensam världsbild med nationen som utgångspunkt (Lundgren, 1979). Även om samhällskrafter fanns vid tidpunkten för folkskolans grundande som förespråkade en skola med medborgarfostrande inriktning och med grund i upplysningsidéer, så vann de krafter som ansåg kristendomsundervisningen som det självklara fundamentet för barnens skolgång.

Folkskolestadgans (1842) syfte uttrycktes i termer av disciplinering och samhörighetsfostran via kyrkan, kristendomen och Luthers lilla katekes. Undervisningen fixerade eleverna i en färdig modell för faktakontroll där inget utrymme gavs för egna reflektioner och frågor (Algotsson, 1975; Lundgren, 1979).

Mot slutet av 1800-talet skedde en rad förändringar i samhället, i demokratiseringens tjänst, som kom att ställa nya krav på skolan. Kristendomsämnets prioriterade ställning i undervisningen och dess uttalade syfte att vinnlägga sig om varje elevs moraliska fostran i nationens intresse och i samhällets tjänst ifrågasattes. Med 1878 års normalplan och 1882 års folkskolestadga kom den struktur och organisation att formas som folkskolan varit i avsaknad av tidigare. 
Hitintills hade ingen föreskriven tidfördelning ämnena emellan funnits och med nya riktlinjer kom timantalet för respektive ämne att regleras. Undantag sattes för kristendomskunskapen som tilläts överskrida den stadgade tiden (Algotsson, 1975; Jonsson, 2016).

När den allmänna folkskolan gick in i ett nytt sekel var det kristendomskunskapens centrala plats i undervisningen som kom att debatteras flitigt. Röster hördes som kritiserade kristendomskunskapens innehåll och dess syfte att tjäna som förkunnelsemedel i undervisningen. Med den undervisningsplan som lanserades år 1919 kom en lång tradition med Luthers lilla katekes i fokus att ersättas med Bibeln som underlag och med ett innehåll för undervisningen i etisk riktning och tankefrihet för den enskilde eleven skrevs in i anvisningarna för kristendomsämnet. Ämnet gavs färre undervisningstimmar till förmån för andra samhällsorienterande ämnen (Undervisningsplan för rikets folkskolor, 1920). Det kan sägas att undervisningen ditintills varit av starkt faktaförmedlande karaktär och kom nu att utmanas av tankar om det diskuterande klassrummet. Denna form av tankefrihet kom dock inte att realiseras under denna våg. Kristendomskunskapens syfte och innehåll stod inte längre i fokus för elevers sociala fostran utan ansvaret flyttades över till skolans arbetssätt, organisation och övriga samhällsämnens innehåll. Även om folkskolan inte längre kom att stå som konfessionellt bunden till den lutherskt protestantiska svenska kyrkan, vilade ämnet på en allmänkristen grund och handlade fortfarande om undervisning $i$ och inte om kristendom (Algotsson, 1975; Jonsson, 2016).

Under den konfessionella vågen kom kristendomsämnet att formas av ett samhälle och en kunskapssyn där kristen uppfostran var av allmänt intresse och gick hand i hand med skolans undervisning (se exempelvis Algotsson, 1975; Lundgren, 1979; Jonsson, 2016). Även om tiden runt 1900-talets första decennier karaktäriseras av en successiv utveckling i demokratisk anda gestaltas den önskade eleven i termer av:

- Lydnad

- Disciplinering

- Underdånighet

Den konfessionella vågen ger uttryck för en undervisning och ett ämne baserat på religiös tro och nationell karaktärsfostran även om röster börjat göra sig hörda värnande om den enskilde individens tankefrihet. Ämnet präglas med andra ord av en stark inramning där skolämnet kristendomskunskap har en tydlig riktning och ett tydligt innehåll som ska överföras från läraren till skolans elever och grusar de förhoppningar med vad Bernstein (1971) benämner integrationskod. Detta gör att gränsen mellan skolämnet och elevens medinflytande, är mycket tydlig, då kunskapen och innehållet fortfarande befästs genom en kollektionskod då undervisningen sker $i$ och inte om kristendom. Den diskursiva ordning som eleverna ska socialiseras in i via ämnet är påtaglig då den alkemi som sätts på spel, genom den pedagogiska psykologins regulativa principer, är tydlig: Eleven ska 
underordna sig samhällets regler och använda sitt förnuft på så vis att hon eller han gör det Gud och fosterlandet kräver (Popkewitz, 2009, 2010).

\section{Kristendoms-/religionskunskapsämnet och den objektiva vågen}

Med den objektiva vågen avses en period från 1950-talet fram till år 1994 (Englund, 2005). Den svenska skolan framstod efter andra världskriget som en otidsenlig institution och krav ställdes på nytt skolsystem med innehåll i samklang med tidens demokratiska anda (SOU 1948:27). Den grundläggande utgångspunkten för nytt skolsystem rörde tankar om en sammanhållen nioårig grundskola med målet att fostra varje elev till demokratiska människor (Prop. 1950:70). I den undervisningsplan som utkom år 1955 anges att ämnet kristendom ska utgå från en icke-konfessionell undervisning (Undervisningsplan för rikets folkskolor, 1955). Mot slutet av 1950-talet tappar kristendomsämnet än mer sin tidigare starka ställning och ses inte längre som skolans viktigaste ämne och självklara ideologi. Andra religioner än den kristna kom att vinna inträde i Sverige och i skolans undervisning. Detta kom att innebära radikala förändringar för religionskunskapsämnet som fick ny ämnesbeteckning: i Lgr 62 ändrades ämnesbeteckningen kristendom till kristendomskunskap och sedermera till religionskunskap gällande från och med Lgy 65 och Lgr 69.

Den tidigare kristendomsundervisningens tid som hade undervisat eleverna $i$ en viss tro ersattes av en undervisning om religioner. De huvudmoment som anges för religionskunskapsämnet i Lgy 65 speglar "sönderbrytandet av den kristna enhetskulturen" med betoning på religionsfrihetskrav och "naturvetenskapens och den därav föranledda världsuppfattningens utveckling” (Lgy 65, s. 146). Även andra attityder till tillvaron än de religiösa skrivs fram med exempel från "djuppsykologins syn på religionen som en tvångsneuros med infantila drag" (Lgy 65, s. 152). Formuleringar som att skolans uppgift är att "söka hjälpa varje elev till allsidig utveckling" (SOU 1961:31, s. 150) och till "prövande objektiv hållning” (s. 173) pekar på ett nytt förhållningssätt i undervisningen. Precis som skrivningarna i SOU 1961:31 ringar in den enskilde individens fostran till allsidighet och objektiv hållning, visar även tidigare forskning att tidsandan signalerar att samhället är på väg i en ny riktning. I sekulariseringens tecken kom begrepp såsom objektivitet och neutralitet att bli vägledande, i framför allt religionskunskapsundervisningen förstärkta med ledorden saklighet, allsidighet och distans (Algotsson, 1975; Hartman, 2010; Jonsson, 2016).

En grundtanke i arbetet med religionskunskapsämnets reformering var att även icke-religiösa livsåskådningar skulle beredas plats i undervisningen med syfte att visa det nya samhällets mångfald av åskådningar. Den enskilde eleven skulle på så vis få en god grund att stå på för att senare kunna göra ett självständigt val av det mångfacetterade utbudet av religiösa och icke-religiösa åskådningar. I undervisningen ställdes dock krav på religiös neutralitet i syfte att skydda eleverna från religiös och livsåskådningsmässig påverkan (SOU 1963:42, s. 359-361). Tidigare forskning visar att den religiösa och ideologiska pluralismen inte kunde 
hanteras i ett religionskunskapsämne baserat på objektivitet och neutralitet. Lärarna försattes i en så kallad objektivitetskramp med rädsla för att avvika från korrekthet när det gäller ett objektivt, neutralt och allsidigt förhållningssätt (Algotsson, 1975; Jonsson, 2016). En existentiell vändning kom att äga rum i och med att begreppet "livsfrågor" lanserades i Lgr 69: "Genom att för eleverna väsentliga frågor tas upp till behandling tillförsäkras elevengagemanget en fundamental roll” (s. 177). Enligt Hartman (2009) innebär detta en vändning från en stoffcentrerad till elevcentrerad undervisning genom de didaktiska möjligheter som nu uppenbarade sig i och med livsfrågeperspektivet.

Tankegångarna från Lgr 69 och de olika religionernas och livsåskådningarnas livstolkande och existentiella betydelse skulle hädanefter vara vägledande $\mathrm{i}$ undervisningen. Formuleringar om elevcentrering återfinns även i Lgy 70 där eleven anmodas att "med bevarad tolerans mot andras uppfattning uppöva sin förmåga till självständigt ställningstagande i livsåskådningsfrågor” (s. 177). Enligt denna läroplans målformulering för religionskunskapsämnet ska eleven förutom att skärpa förmågan till självständigt ställningstagande i livsåskådningsfrågor, orientera sig i moraliska och religiösa problem, skaffa sig kunskap om olika livsåskådningar samt öka kunskaperna i såväl kristendom som andra religioner (Lgy 70; Jonsson, 2016). Tidigare forskning visar hur det vi benämner som den objektiva vågen, kristendoms-/religionskunskapsämnet och dess innehåll förändras över tid; ett konfessionellt innehåll fick ge vika för en objektiv och pluralistisk förståelse av religion där den existentiella vändningen ställer nya förväntningar på eleven. Den objektiva vågen ger uttryck för en önskad elev som har:

- Öppet sinne för kristendom

- Kunskap om religionernas och livsåskådningarnas värld

- Fokus på existentiell pluralism och kristen etik

Under den objektiva vågen navigerar ämnet från ett totalt fokus på kristna trosföreställningar till en medvetenhet av olika religioners trosföreställningar. Eftersom ämnets innehåll och undervisning också ska inbegripa världsreligioner, livsfrågor och pluralism för att avspegla det omgivande samhällets realitet, lämnar ämnet under denna våg den starka kollektionskod som är så kännetecknande för ämnets första våg, mot en integrationskod genom att sätta eleven i centrum, även om kollektionskoden syns tämligen stark när det kommer till den objektivitet och kunskapsorientering som ämnet präglas av (Bernstein, 1971). Till skillnad från den förra vågens diskursiva ordning baserad på Gud och fosterlandet, ska eleverna formas till mer självständiga individer med en öppen blick mot omvärlden och religiösa uttrycksätt och livsval. Den styrande principen är emellertid objektivitet, snarare än individuell förståelse av omvärlden (Popkewitz, 2009, 2010). 


\section{Religionskunskapsämnet och den osäkra vågen}

Med den läroplan för gymnasieskolan som lanserades år 1994 (Lpf 94), tenderar religionskunskapsämnet att, enligt Skolverket (2007), bli "något annat” där stor osäkerhet råder om ämnets precisering. Även om det inte går att peka på någon specifik förklaring till varför religionskunskapsämnet framstår som problematisk, formulerar Skolverket några frågeställningar: Går det att bedöma elevers kunskaper vad gäller tro, etik och syn på livet? Är livsfrågor ett kunskapsområde och var finns den röda tråden i ämnet? Religionsämnets spännvidd och innehåll omfattar såväl teoretiska kunskaper som personliga reflektioner men här finns även en inbyggd problematik: "Risken för stoffträngsel är uppenbar och strävan efter en helt rättvis betygsättning kan leda till att kunskapsområden som livsfrågor och etik inte får det utrymme som kursplanen anger” (Skolverket, 2007). Detta menar Skolverket är olyckligt eftersom stoffträngseln riskerar "innebära ett läge där behovet av repetition krockar med gymnasieskolans krav på fördjupning” (Skolverket, 2007). Då förlorar också religionskunskapsämnet sitt integrerande uppdrag som en "fördjupning av skolans medborgarfostrande uppgift" (Skolverket, 2000, s. 80; SOU 2008:27, s. 237).

Karaktäristiskt för kursplanen är att den är i avsaknad av stoffangivelser. Val av innehåll åläggs lärarna på lokal nivå och samtliga lärare bär ansvaret för att etiska frågeställningar lyfts fram i skolans undervisning oavsett ämne i enlighet med läroplanens värdegrund. Emellertid har religionskunskapsämnet fătt ta huvudansvaret för etiken då den i kursplanen gestaltas som en del av ämnets karaktär: "Att bearbeta existentiella frågor och trosfrågor och att beakta tillvaron utifrån etiska perspektiv ingår i en personlig utvecklingsprocess" (Lpf 94, s. 38). Läroplanens framskrivning av ämnets karaktär, struktur och innehåll till trots förefaller ämnet vara konturlöst, diffust och med alltför stor spännvidd (Jonsson, 2016).

Det var under denna våg som traditionella välfärdsstatsideal fick ge vika för tilltron till marknadslösningar och till individens fria val och det ena området efter det andra avreglerades, inklusive den statligt styrda skolan. Begreppet valfrihet lyftes nu fram i den politiska debatten. Valfrihet, individualisering och decentralisering utgjorde förutsättningar för att kommersialisera välfärden. Den genomgripande omvandlingen av den statliga styrningen av skolan som inleddes åren kring 1990 karaktäriseras av en övergång från regelstyrning till mål- och resultatstyrning där kommunerna ersatte staten som huvudman. Därefter kom först friskolereformen, därefter det fria skolvalet och skolpengen tillsammans med profilerade utbildningsalternativ och implementeringen av målrelaterade läroplaner för grundskola och gymnasieskola (Broady, 2000). I relation till denna utveckling och läroplansreformer kom skolan att bli en sak mer för individen än för kollektivet och detta märks även i olika ämnen, med målrelaterade betyg, individorienterade vägar till lärande och så vidare. Det konfessionsfria religionskunskapsämnet fokuserar elevens egen förståelse för vad som kan läras av religioner och mänskliga möten. Olika existentiella tillstånd och 
livsåskådningar kretsar kring begreppen livsfrågor, etik och reflektion. Den önskade eleven förväntas vara:

- Livskompetent med kunskaper om religioner och livsåskådningar

- Vidsynt och reflekterande

- Öppensinnad för religiös och existentiell mångfald

Undervisning såväl som religionsämnet baseras på olika religioner, livsåskådningar och trosföreställningar, dock med en underström i kursplanen som leder skolans fostrande roll tillbaka till den kristna traditionens särställning. Ämnets utveckling går, under denna våg, mot en tydlig integrationskod, med fokus på såväl elevnära frågor som kunskaper om religioner och livsåskådningar. Till skillnad från Bernsteins (1971) begrepp kollektionskod, som karaktäriseras av ett ämnes tydliga inramning och legitimitet, tycks religionskunskapsämnet sakna såväl struktur som avgränsning. Den diskursiva ordning som reglerar religionskunskapsämnets innehåll i enhetlighet med religionskunskapsämnets psykologiska principer som sätts på spel genom den liberala avreglerade samhällsordningen, handlar om att forma en självständig och individuell elev som avspeglar den mångfald och individualisering som uttrycks såväl i samhälle som i skola och klassrum (Popkewitz, 2009, 2010).

\section{Ett reformerat ämne - mot en objektiv våg 2.0?}

Många har de debatter varit som föregått 2011 års kurs- och ämnesplaner för såväl grund- som gymnasieskola. Oenigheter har förekommit rörande frågan om hur kristendomskunskapen inom ämnet religionskunskap bör och ska formuleras. Med argument baserade på det faktum att Sverige och dess befolkning under lång tid präglats av just kristendom har politiska röster betonat kristendomskunskapens framskjutna position i undervisningen och som därför bör ta den jämförelsevis största platsen i förhållande till övriga världsreligioner. Med ämnesplanen för gymnasiet (Gy 11) aviseras ett rationaliserande, kunskapsinhämtande och faktabaserat förhållningssätt till religioner och andra livsåskådningar. Religionskunskapsämnet skrivs också fram som ett ämne med vetenskaplig förankring i religionsvetenskap och även som ett ämne med tvärvetenskaplig karaktär. Religionskunskapsämnets existentiella sida med utgångspunkt i elevers egna livsfrågor har tonats ner. Begrepp som livsfrågor, etik samt reflektion har fått stå tillbaka för begrepp såsom kunskaper och analys (Lpf 94; Gy 11; Kittelmann Flensner, 2015). Ämnesplanen präglas av en, i förhållande till den tidigare kursplanen från 1994, teoretisk och akademisk vokabulär med betoning på religionsvetenskap där också religionens relation till vetenskapen ingår som ett särskilt moment. En förskjutning har ägt rum från ett individuellt elevnära perspektiv med fokus att "få möjlighet att reflektera över existentiella och etiska frågor utifrån olika perspektiv” (Lpf 94, s. 42) till ett ämne riktat främst på kunskap om olika religioner och livsåskådningar och analytisk kunskap (Gy 11). 
Skolans reformering följer tidsandans liberala marknadsreformer. Den avreglerings- och valfrihetsreform som följde efter kommunaliseringen av skolan under tidigt 1990-tal tillsammans med implementeringen av nya och målrelaterade läroplaner för grundskola och gymnasium, kom under det nya milleniet att intensifieras och kommunalisering av skolan drevs till en marknadisering av densamma (Gustavsson, Sörlin \& Vlachos, 2016). Det utbildningspolitiska tonläget om skolans roll och plats i samhället handlar om tolkningsföreträde och präglas i mångt och mycket av det den amerikanske pedagogen Michael W. Apple (1993) beskriver som ett mellanting mellan nykonservativas värden och neoliberala marknadsvärderingar. Å ena sidan minskar statens roll genom att privata företag kommer in på utbildningsmarknaden, samtidigt som - å andra sidan trycket ökar på en gemensam eller allenarådande föreställning om vad en bra lärare är, vad riktig kunskap är, vilka normer och värderingar som ska råda inom skolans värld (Månsson, 2014). Denna utveckling, som i första hand fokuserar den enskilda individen, gör att skolans roll som fokuserar demokratisk fostran och social utveckling framstår som mindre relevant för det framtida samhälleliga deltagandet.

I linje med denna utveckling - som likt den objektiva vågen främst tar fasta på faktakunskaper och analytisk förmåga - förs religionskunskapsämnet tillbaka till 1960-talets objektiva våg och faktaorienterade ämnesplaner (Kittelmann Flensner, 2015). Den önskade eleven förväntas uppvisa:

- Vetenskapligt och rationellt förhållningssätt till religioner och andra livsåskådningar

- God och vetenskaplig kunskap om kristendom

- God och vetenskaplig kunskap om övriga världsreligioner

Religionskunskapsämnets innehåll baseras på fakta om olika religioner och livsåskådningar snarare än dess trosföreställningar och medger därför inget större utrymme för existentiella inslag eller funderingar. Den kristna underströmmen från Lpf 94 kommer upp till ytan då den betonar kristendomens särställning över andra religioner och som leder skolans fostrande roll tillbaka till kristendomens särställning. I en jämförelse med ämnets utveckling under den osäkra vågen är det Bernstein (1971) kallar kollektionskoden, mer framträdande än integrationskoden eftersom elevinflytandet och den elevcentrering som betonas och utvecklas under den objektiva vågen, blir svagare i relation till ämnets tydligare avgränsning och det vetenskapliga och rationella förhållningssätt som ämnet ska bemötas av. Den alkemi som sätts på spel genom ämnets diskursiva ordning inordnar eleven i en regelbundenhet och ordning som hon eller han inte själv har någon direkt kontroll över (Popkewitz, 2009, 2010) och stämmer helt överens med tidsandans slagord om mer ordning och reda samt kunskap och kontroll i skolan. Den önskade eleven ska genom religionskunskapsämnet socialiseras i denna anda och lära sig att bruka sitt förnuft och sin kunskap som denne lärt sig, det vill säga på ett objektivt, rationellt och analytiskt sätt (Månsson, 2014). 


\section{Diskussion och konklusion}

Syftet med denna artikel var att med utgångspunkt i Gy 11 förstå vad kristendomsämnets, sedermera religionskunskapsämnets innehåll och syfte inneburit för skolans fostrande uppdrag över tid. Ett andra syfte var att diskutera och problematisera de didaktiska implikationer som följer av revideringen av religionsämnet i Gy 11 ur såväl ett allmändidaktiskt som ett ämnesdidaktiskt perspektiv.

För att konkretisera ämnets utformning och fostrande ambitioner över tid användes termerna "alkemi" samt "inramning och avgränsning". Med alkemi avsågs den process där ett ämne lösgörs från sin vetenskapliga disciplin och anpassas till ett skolämne. I denna process är det inte enbart fråga om ett innehåll som eleverna ska tillägna sig, utan det handlar också om att fostra den uppväxande generationen till goda samhällsmedlemmar, det Popkewitz (2004) kallar det önskade barnet. Med inramning och avgränsning avsågs ämnets innehåll i relation till lärarnas frihet att förmedla detta ämnesinnehåll. Beroende på om inramningen, det vill säga gränserna, är starka inom ett ämne i relation till andra ämnen och dess innehåll är tydligt, är det också tydligt vad ämnet ska handla om och hur detta bäst ska förmedlas till eleverna, det Bernstein (1971) benämner som kollektionskod. Om ramarna för ett ämne är otydliga så att ämnesgränserna suddas ut och ämnena integreras med varandra tillsammans med elevernas skolkunskaper och deras vardagliga kunskaper, är det mer otydligt vem som har rätten att definiera dess innehåll och undervisningssätt, det Bernstein (1971) kallar för integrationskod. Det bör noteras att dessa koder inte avlöser varandra utan dess dominans varierar mellan olika ämnen och för ett givet ämne över tid (Goodson, 2005).

För att uppfylla vårt syfte antogs ett läroplansteoretiskt perspektiv för att belysa det nutida religionskunskapsämnets ambitioner, med avseende på såväl syfte som innehåll, i ett historiskt och konceptuellt perspektiv med ett speciellt fokus på ämnets fostrande ambitioner. Genom en konceptualisering av ämnet över tid identifieras fyra vågor som styrt ämnets syfte, innehåll och ambitioner, nämligen en konfessionell våg, en objektiv våg, en osäker våg och en sista våg som vi valt att benämna den objektiva vågen 2.0?. Den första vågen ringar in och uttrycker ett avgränsat och inramat kristendomsämne med såväl tydligt syfte som innehåll. Den önskade eleven är dock ett lydande och underdånigt barn med rötter i den kristna läran. Med den andra vågen sker ett nytt attitydskapande med utgångspunkt i en objektiv orientering som är den önskvärda utvecklingen när det gäller religionskunskapsämnet. Den önskade eleven är vidsynt och tolerant med en god förståelse för kristendom och andra religioner samt existentiell pluralism. Med den tredje vågen visas ett religionskunskapsämne med stor spännvidd och gränslöst innehåll men som också bär spår av konfessionella traditioner bakåt i tiden. Med en snävare inramning genom den kristna underströmmen eftersöks en vidsynt elev med god förståelse för religiös och existentiell mångfald förankrat i en kristen tradition och västerländsk humanism. Den kristna underströmmen når i och med den fjärde vågens inramning ytan. Inramningen och avgränsningen sker 
genom ett fokus på faktakunskaper och ett mer objektivt analytiskt förhållningssätt. Syftet med detta är att den önskade eleven ska erhålla en vetenskaplig syn på och god kunskap om kristendom, övriga världsreligioner och andra livsåskådningar. Med en kunskap om olika religioner och en analytisk kunskap är det möjligt att se samma kunskapssyn som präglade ämnets andra våg (se också Kittelmann Flensner, 2015, för en liknande diskussion). Därav benämningen: $M o t$ en objektiv våg 2.0?

För att avrunda diskussionen kring artikelns första syfte är det med hjälp av Bernsteins (1971) förståelse av ett ämnes inramning och avgränsning möjligt att se hur kristendomsämnet, sedermera religionskunskapsämnet gått från att karaktäriseras av en stark kollektionskod under den första vågen, till att öppna upp för en integrationskod under andra vågen, även om kollektionskoden är tämligen stark. Detta blir allt mer tydligt under den tredje vågen, då kollektionskoden försvagas något mer, för att avgränsas allt mer i favör för en kollektionskod under den sista vågen i ämnets historia då ämnets inramning och avgränsning förtydligas.

Artikelns andra syfte är att diskutera några didaktiska implikationer som följer av revideringen av religionsämnet i Gy 11, i såväl ett allmändidaktiskt som ett ämnesdidaktiskt perspektiv. Inledningsvis beskrev vi didaktikens karaktäristika och delade upp den i en allmändidaktisk del och en ämnesdidaktisk del men utan att särskilja dem helt. I detta sammanhang blir begreppet alkemi synnerligen relevant då det inte enbart handlar om vad en elev ska kunna och kunskapskurvans progression över tid, utan också vilka värderingar och normer, människosyn, attityder och så vidare som eleven ska utveckla under sin resa i skolans olika årskurser och stadier.

Alkemin gör det möjligt att se religionskunskapsämnets fostrande ambitioner också som en del av den allmänna didaktiken snarare än enbart som ett ämne eller kunskapsinnehåll som ska förmedlas, bedömas och betygsättas. Enligt Popkewitz (2009, 2010) opererar ett ämnes alkemi på två plan och det ena är att organisera disciplinen i enhetlighet med skolämnets struktur och innehåll som beskriver vad en elev ska lära sig i ämnet och hur detta ska ske. Den andra nivån är mer diskursiv, där ämnets innehåll organiseras med den pedagogiska psykologins regulativa principer, genom vilka eleven ska anpassas till en viss regelbundenhet och kontrollerad ordning. I relation till ämnets innehåll, strävansmål och bedömningskriterier i ämnesplanen för religionskunskapsämnet blir de ämnesdidaktiska aspekterna tydliga då lärarens uppdrag är att förmedla och kommunicera ett givet innehåll för eleverna, vars kunskaper om detta innehåll sedan ska bedömas och betygsättas utifrån givna kriterier.

När det kommer till ämnets allmändidaktiska aspekter i relation till skolans skrivelser om likvärdighet, tolerans och respekt händer något annat: Att "utveckla respekt och förståelse för olika sätt att leva" och "vidsynthet, öppenhet och förståelse för olika religioner och livsåskådningar än sin egen” är delar av 
religionsämnets kunskapsmål men som är svårare att bedöma och betygsätta än exempelvis elevers "kunskaper om religioner, livsåskådningar och etiska förhållningssätt och olika tolkningar när det gäller dessa”. I båda fallen handlar det lika mycket om att gestalta och reflektera över skolans och samhällets värdegrund och dess innehåll, som att förmedla och reflektera över kunskaper om religioner och livsåskådningar och dess plats i ett mångreligiöst och sekulariserat samhälle. Vidsynthet, öppenhet och förståelse är förmågor och mål med undervisningen som inte på ett enkelt sätt kan förmedlas från lärare till elev men kan ändå inte separeras från ämnets övriga innehåll. Oavsett vilka ambitioner - dess syfte och innehåll - ett ämne har, får dess organisering vissa didaktiska implikationer och nedan har vi, i relation till artikelns inledande problematisering, identifierat tre sådana i relation till såväl elev, klassrum som samhälle:

1. I relation till ovanstående diskussion om "vidsynthet, öppenhet och förståelse för olika religioner och livsåskådningar än sin egen" blir en uppenbar allmändidaktisk implikation att eleverna riskerar att inte komma i kontakt med andra existentiella perspektiv eller att utveckla sina egna perspektiv då "elev-nära” frågor ges såväl mindre utrymme som betydelse. I kölvattnet av denna allmändidaktiska konsekvens finns också en ämnesdidaktisk implikation, nämligen att religionskunskapsämnet riskerar att falla tillbaka i rena ämneskunskaper som är lätta att lära ut, kontrollera samt bedöma och betygsätta, eftersom det handlar att lära sig om och inte $a v$ andra religioners och livsåskådningars synsätt och uttrycksformer.

2. Den andra allmändidaktiska implikationen, som också får ämnesdidaktiska konsekvenser, är mer orienterad mot samhället som sådant och berör frågan om vad som händer när ett ämne ”abdikerar” från sitt samhälleliga uppdrag. För att förtydliga: syftet med ämnet har inte abdikerat, utan dess nya innehåll och fokus på vetenskaplighet och objektivitet gör att det omgivande samhällets karaktäristika inte till fullo avspeglas. Den pluralitet av religioner och livsåskådningar som befolkar ett klassrum eller en skola finns också i samhället och skolan är inte en värld för sig, den hänger samman med och avspeglar det omgivande samhällets karaktäristika. Om eleverna saknar kunskaper och erfarenheter om andra existentiella perspektiv eller livsåskådningar än sin egen, hur lyckas då ämnet att utöka människans syn på världen?

3. En tredje och tydlig ämnesdidaktisk implikation är knuten till lärarens uppdrag och förhållningssätt när denna ska prata om något objektivt, som exempelvis trosbekännelsen, med en elev som befinner sig i denna på ett subjektivt plan. Det objektiva faktabaserade perspektivet riskerar att förlora sin igenkänningsfaktor då läraren inte ges möjlighet att nyansera bilderna, om exempelvis olika trosföreställningar och dess uttrycksformer, utan att ta hänsyn till ett elevnära och subjektivt perspektiv. 
För att närma sig religionskunskapsämnet ur ett inifrånperspektiv, där elever från olika religiösa och kulturella traditioner kan känna tillit till innehållet, undervisningen och läraren, måste läraren stundtals avvika från ett utifrånperspektiv, och visa att ämnet innehåller mer än faktabaserade kunskaper om religioner och livsåskådningar. Hur religionskunskapslärare på gymnasiet behandlar religionskunskapsämnet, dess syfte och innehåll i sina klassrum är emellertid en empirisk fråga eftersom det handlar om vad läraren faktiskt gör och hur denne ser på sitt uppdrag som lärare. För att belysa och förstå hur kursplansreformen för religionskunskapsämnet tagits emot av lärare i ämnet, hur de förhåller sig till ämnets innehåll och hur undervisningen planeras och genomförs, behövs det med andra ord mer empirisk forskning där verksamma religionslärares egna berättelser om sin undervisningspraktik sätts i förgrunden.

\section{Om författarna}

Linda Jonsson är lektor i didaktik vid Mälardalens högskola. Med bakgrund som gymnasielärare i ämneskombinationen religion, historia och svenska arbetar hon nu bland annat inom lärarutbildningen och undervisar främst i utbildningsvetenskapliga kurser. I det övergripande forskningsintresset fokuseras didaktik och pedagogik och detta gärna i relation till (religions)läraruppdraget.

Institutionsanknytning: Akademin för utbildning, kultur och kommunikation, Mälardalens högskola, 63105 Eskilstuna, Sverige.

E-post: linda.jonsson@mdh.se

Niclas Månsson är professor i allmän pedagogik vid Södertörns högskola. Hans forskning befinner sig inom det utbildningsfilosofiska och allmändidaktiska fältet med intresset främst riktat mot hur skolans fostrande roll ses i relation till det omgivande samhället och där utbildningens innehåll sätts i relation till mångfald, demokrati, etik och utbildningspolitik. Han bedriver även empirisk forskning om unga människors utbildningsvägar i relation till migration, socialt kapital och utbildningsbakgrund.

Institutionsanknytning: Institutionen för kultur och lärande, Södertörns högskola, 14189 Huddinge, Sverige.

E-post: niclas.mansson@sh.se 


\section{Referanser}

Algotsson, K.-G. (1975). Från Katekestvång till religionsfrihet. Debatten om religionsundervisningen i skolan under 1900-talet. Uppsala: Rabén \& Sjögren.

Alvesson, M. \& Sköldberg, K. (2017). Tolkning och reflektion. Vetenskapsfilosofi och kvalitativ metod. (Andra upplagan.) Lund: Studentlitteratur.

Apple, M. W. (1993). Education and the Conservative Restauration: Moral Logics and Genetic Explanations. I I. Nilsson \& L. Lundahl (red.), Teachers, Curriculum and Policy: Critical Perspectives in Educational Research (s. 11-26). Umeå: Department of Education.

Bernstein, B. (1971). On Classification and Framing of Educational Knowledge. I M. Young (red.), Knowledge and Control: New Directions of Sociology of Education (s. 47-69). London: McMillan.

Blankertz, H. (1987). Didaktikens teorier och modeller. Stockolm: HLS Förlag.

Britton, T. H. (2019). Att möta det levda. Möjligheter och hinder för förståelse av levd religion i en studiebesöksorienterad religionskunskapsundervisning. Doktorsavhandling, Stockholms universitet. https://www.divaportal.org/smash/get/diva2:1356856/FULLTEXT01.pdf

Broady, D. (2000). Inledning. I D. Broady (red.), Skolan under 1990-talet. Sociala förutsättningar och utbildningsstrategier (s. v-xi). Rapport till kommittén Välfärdsbokslut. Rapporter från Forskningsgruppen för utbildnings- och kultursociologi, nr. 27. Uppsala universitet. https://uu.diva-portal.org/smash/get/diva2:328641/FULLTEXT01.pdf

Bronäs, A. \& Runebou, N. (2010). Ämnesdidaktik - en undervisningskonst. Lund: Studentlitteratur.

Englund, T. (1992). Tidsanda och skolkunskap. I G. Richardsson (red.), Ett folk börjar skolan. Folkskolan 150 år 1842-1992 (s. 88-111). Stockholm: CE Fritzes AB.

Englund, T. (2005). Läroplanens och skolkunskapens politiska dimension. Göteborg: Daidalos.

Englund, T. (2007). Om relevansen av begreppet didaktik. Acta Didactica Norge, 1(1), 1-12. https://doi.org/10.5617/adno.1013

Fancourt, N. P. M. (2008). Self-Assessment in Religious Education. Doctoral dissertation, University of Warwick. http://wrap.warwick.ac.uk/1108/1/WRAP_THESIS_Fancourt_2008.pdf

Goodson, I. F. (2005). Becoming an Academic Subject. I I. F. Goodson (red.), Learning, Curriculum and Life Politics: the selected works of IVOR F. GOODSON (s. 52-68). London: Routledge.

Hartman, S. (2009). Fyrtio år. Religion \& Livsfrågor, (4), 6-9.

Hartman, S. (2010). Det pedagogiska kulturarvet: Traditioner och idéer i svensk undervisningshistoria. Stockholm: Natur \& Kultur.

Holmqvist Lidh, C. (2016). Representera och bli representerad: elever med religiös positionering talar om skolans religionskunskapsundervisning. Licentiatavhandling, Karlstads universitet. http://kau.divaportal.org/smash/get/diva2:1038308/FULLTEXT01.pdf

Grimmitt, M. (1987). Religious Education and Human Development. Great Wakering: McCrimmons.

Gustavsson, J.-E., Sörlin, S. \& Vlachos, S. (2016). Policyidéer för svensk skola. Stockholm: SNS Förlag.

Gy 11. Läroplan, examensmål och gymnasiegemensamma ämnen för gymnasieskola 2011. Stockholm: Skolverket. 
https://www.skolverket.se/undervisning/gymnasieskolan/laroplan-program-och-amnen-igymnasieskolan/laroplan-gy11-for-gymnasieskolan

Jackson, R. (red.) (2019). Special Issue: Signposts and the Council of Europe: The Contribution of 'Inclusive' Religious Education to Intercultural Understanding. Intercultural Education, 30(3), 237-334. doi.org/10.1080/14675986.2019.1539356

Jonsson, L. (2016). Mellan tradition och förnyelse - utmaningar i religionsläraruppdraget. Doktorsavhandling, Mälardalens högskola. http://mdh.divaportal.org/smash/get/diva2:1033199/FULLTEXT01.pdf

Kittelmann Flensner, K. (2015). Religious Education in Contemporary Pluralistic Sweden. Doktorsavhandling, Göteborgs universitet. https://gupea.ub.gu.se/bitstream/2077/40808/1/gupea_2077_40808_1.pdf

Kittelmann Flensner, K. (2018). Levd religion i klassrummet. I K. Plank \& D. Enstedt (red.), Levd religion: det heliga i vardagen (s. 258-274). Lund: Nordic Academic Press.

Kittelmann Flensner, K. \& von der Lippe, M. (2019). Being safe from what and safe for whom? A critical discussion of the conceptual metaphor of 'safe space'. Intercultural Education, 30(3), 275-288. https://doi.org/10.1080/14675986.2019.1540102

Kongl. Maj:ts Nådiga Stadga angående Folk-underwisningen i Riket (1842). Stockholm: Stockholms slott. http://ncm.gu.se/media/kursplaner/grund/LL1842.pdf

Kongl. Maj:ts förnyade nådiga stadga angående folkundervisningen i riket (1882). Stockholm: Stockholms slott. http://ncm.gu.se/media/kursplaner/grund/LL1842.pdf

Lgr 62. Läroplan för grundskolan 1962. Stockholm: Kungliga Skolöverstyrelsen. https://gupea.ub.gu.se/handle/2077/50232

Lgr 69. Läroplan för grundskolan, 1969. 1, Allmän del. Stockholm: Utbildningsförlaget. https://gupea.ub.gu.se/handle/2077/30902

Lgy 65. Läroplan för fackskolan 1965. Kursplan för religionsvetenskap. Stockholm. https://gupea.ub.gu.se/handle/2077/50609

Lgy 70. Läroplan för gymnasieskolan 1970. Stockholm: Skolöverstyrelsen och Liber Utbildningsförlaget. https://gupea.ub.gu.se/bitstream/2077/31275/1/gupea_2077_31275_1.pdf

Lpf 94. Läroplan för de Frivilliga Skolformerna. Särskilda Programmål för Gymnasieskolans Nationella Program. Kursplaner i Kärnämnen för Gymnasieskolan och den Gymnasiala Vuxenutbildningen. Stockholm: Utbildningsdepartementet. https://www.skolverket.se/publikationer?id=1071

Lundgren, U. P. (1979): Att organisera omvärlden. En introduktion till läroplansteori. Stockholm: Liber Förlag.

Månsson, N. (2014). Skolan, barnet och samhällslivet. I A. Burman (red.), Den reflekterade erfarenheten: John Dewey om demokrati, utbildning och tänkande (s. 189-203). Södertörn Studies in Higher Education.

Nordmark, J., Jonsson, L. \& Månsson, N. (2018). Att bilda eller bedöma. Om skapandet av demokratiska medborgare. Nordisk Tidskrift för Allmän Didaktik, 4(2), 3-16.

Normalplan för undervisningen i folkskolor och småskolor, 1878. Stockholm: P. A. Norstedt \& söner. https://gupea.ub.gu.se/handle/2077/54763

Olson, M. (2017). Det oväntade i so-ämnenas undervisning - bjudningar till annat kunskapande och tillblivande. Nordidactica, 2, 1-7. https://journals.lub.lu.se/nordidactica/article/view/19038/17229

Osbeck, C., Sporre, K. \& Skeie, G. (2017). The RE classroom as a safe space. Critical perspectives on dialogue, demands for respect, and nuanced religious education. I M. Rothangel, K. von Brömssen, H. Heimbrock \& G. Skeie (red.), Location, Space and Place in Religious Education (s. 49-66). Münster: Waxmann. 
Popkewitz, T. S. (2002). How the Alchemy Makes Inquiry, Evidence, and Exclusion. Journal of Teacher Education 53(3), 262-267. https://doi.org/10.1177/0022487102053003011

Popkewitz, T. (2004). The Alchemy of the Mathematics Curriculum: Inscriptions and the Fabrication of the Child. American Educational Research Journal, 41(1), 3-34. https://doi.org/10.3102\%2F00028312041001003

Popkewitz, T. (2009). Kosmopolitism i skolreformernas tidevarv. Vetenskap, utbildning och samhällsskapande genom konstruktionen av barnet. Stockholm: Liber.

Popkewitz, T. (2010). The Limits of Teacher Educational Reforms: School Subjects, Alchemies, and an Alternative Possibility. Journal of Teacher Education, 61(5), 413-421. https://doi.org/10.1177/0022487110375247

Prop. 1950:70. Angående riktlinjer för det svenska skolväsendets utveckling. Stockholm: Regeringskansliet. https://lagen.nu/prop/1950:70

Religion \& Livsfrågor (2011). Temanummer: Nya kurs- och ämnesplaner i religionskunskap (2). Föreningen lärare i religionskunskap.

Skolinspektionen (2012). Mer än vad du kan tro. Religionskunskap i gymnasieskolan. Skolinspektionens kvalitetsrapport 2012:3. Stockholm. https://www.skolinspektionen.se/globalassets/02-beslut-rapporterstat/granskningsrapporter/tkg/2012/religion/slutrapport---religionskunskap-igymnasieskolan-2012.pdf

Skolverket (2000). Reformeringen av gymnasieskolan - en sammanfattande analys. Skolverkets rapport, 187. Stockholm. https://www.skolverket.se/download/18.6bfaca41169863e6a653a3a/1553956860204/pdf6 39.pdf

Skolverket (2007). Perspektiv på religionskunskap. Stockholm: Skolverket. (Borttagen från Skolverkets hemsida.)

SOU 1948:27. 1946 års skolkommissions betänkande med förslag till riktlinjer för det svenska skolväsendets utveckling. Stockholm. https://lagen.nu/sou/1948:27

SOU 1961:31. Läroplaner för grundskolor och fackskolor. Förslag angivet av 1957 års skolberedning. Stockholm. https://lagen.nu/sou/1961:31

SOU 1963:42. Ett nytt gymnasium. Stockholm. https://lagen.nu/sou/1963:42

SOU 2008:27. Framtidsvägen - en reformerad gymnasieskola. Stockholm. https://www.regeringen.se/rattsliga-dokument/statens-offentliga-utredningar/2008/03/sou200827/

Säfström, C. A. \& Östman, L. (1999a). Introduktion: Om epistemologi, språk och pragmatism. I C. A. Säfström \& L. Östman (red.), Textanalys: Introduktion till syftesrelaterad kritik (s. 15-26). Lund: Studentlitteratur.

Säfström, C. A. \& Östman, L. (1999b). Syftesrelaterade analyser och kritik. I C. A. Säfström \& L. Östman (red.), Textanalys: Introduktion till syftesrelaterad kritik (s. 115-120). Lund: Studentlitteratur.

Undervisningsplan för rikets folkskolor 31 oktober 1919. Publicerad den 17 mars 1920. Stockholm: P.A. Norstedt \& Söners Förlag. https://gupea.ub.gu.se/handle/2077/51541 Undervisningsplan för rikets folkskolor den 22 januari 1955. Stockholm: Skolöverstyrelsen. http://ncm.gu.se/media/kursplaner/grund/LL1955.pdf

von der Lippe, M. (2010). Youth, religion and diversity - a qualitative study of young people's talk about religion in a secular and plural society: a Norwegian case. Doktorsavhandling, Stavanger universitet.

von Oettingen, A. (2018). Allmän didaktik: mellan normativitet och evidens. Lund: Studentlitteratur. 